\title{
James I and Sir Edward Coke
}

NE of the best-known incidents of the reign of James $I$ is that meeting of the judges before the king in which Coke contradicted Archbishop Bancroft and declared that the king had no right to decide cases in person. Bancroft had appealed to the king to decide a matter in dispute between him and the judges, on the ground that the judges being merely delegates of the crown, James might draw the case out of the courts and hear it himself. Coke declared roundly that such a proceeding was not warranted by law. The king replied that ' he thought the law was fonnded on reason, and that he and others had reason as well as the judges.' Coke then said, according to the account in his Tuelfth Report, that

true it was that God had endored his majesty with excellent science ar. 3 grest endowments of nature; bat his majesty was not learned in the iy: : of his realm of England, and causes which concern the life or ininerit. ance, or goods, or fortunes, of his subjects; they are not to be decided by natural reason, bat by the artificial reason and judgment of law, which law is an act which requires long study and experience before that a man can attain to the cogniance of it; and that the law was the golden metwand and measure to try the causes of the subjects; and which protected his majesty in safety and peace. With which the king was greatly offended, and said, that then he sliould be under the lsw, which was treason to affirm, as he said. To which I said that Bracton saith Quod rex non debct esse stbb homine sed sub Deo ct lege.'

Certain manuscripts at Hatfield House and elsewhere seem to throw some doubt upon this famous account of a famous intervier, bat before we turn to their evidence it will be necessary to show that the presence of this account among Coke's Reports is no prima facie guarante of its correctness. It is well known that the twelfth and thirteenth volumes of the Reports (which contain nearly all the material of value to the historian) were published many years after Coke's death and under circumstances which cast doubt upon their correctness. In Jul.' 1694, a few months before Cole's death,' Windebank, by order of the king, seized all his papers. ${ }^{2}$

1 Reports, zii. 65; Gardiner, Hist of Engl. ii. 89

- Cole died 3 Sept. 1634. ' Cial. of S. P., Dom., Charles I, 1634-5, p. 165. 
In 1641 one of Coke's sons moved in the house of commons that the papers be restored to Sir Robert Coke, the heir of the chief justice. The king consented, and the papers, 'such as could be found,' were delivered again to the family. What happened to them during that period no nne knows with any exactness. Fifteen years after their return to the family some of these papers were collected, translated from the law French in which they had been originally written into English, and published in two volumes, the one in 1656 as the twelfth and the other in 1659 as the thirteenth book of the Reports of Sir Edicard Colie. There are still several manuscript copies in law French of these two books: Hargrave MS. 34, a selection only; Lansdowne MS. 601, Lord Hales's copy; Lansdowne MS. 1079; Harleian MS. 4815-6; Maynard's MS. 80, in the library of Lincoln's Inn; and a fragment in Petyt MS. 518, ff. 1-7, in the Inner Temple. But there is no evidence of any lind that these were copied from Coke's manuscripts or that any one of them was compared with the originals, or even that any person ever saw Coke's manuscripts. 'Indeed, the one person who we should suppose had seen the original book or papers distinctly states that he did not see the book until it was in the printed form which we now have.

In relation to some reports lately publisbed and stiled by the name of the twelfth part of Sir Edward Coke's Reports [wrote Bulstrode in the preface to his own Reports], whereunto my name is subscribed by way of approbation, as if I had perused the MS. before it came to the Presse. I must confesse the Book was brought to me, after it was fally Printed, and not before, with a desire that I would read and peruse it. . . . I did accordingly carefully read and peruse it, but found therein as many grosse mistakes, omissions, misprintings, and imperfections that I told the Party that brought it, that it was not fit for publike view, with so many defects in it, but that I did conceive they were the Collections of Sir Edward Coke, and that there were many good and useful cases in them: but never fitted nor prepared for the Presse; but notwithstanding this they were printed and published with all the defects and mistakes in them.

These volumes of the Reports can therefore hardly be considered as historical evidence of the first anthority.

The volume of which Bulstrode so speaks contains many traces of the most careless and ancritical editing. For instance, on ff. $27,28,37,38,131$ of the twelfth book are statements about au act of 10 Elizabeth, in which year no parliament met. It is, of course, a mistake in the copying of ' $1^{\circ}$ Elizabeth,' and the statute referred to is 1 Eliz. c. 1. On'f. 109 of the twelfth book is a paper dated 'Hil.

- Hoger Coke states that Bir Edward left one in collectod form (Detection, i. 809), the twellth; but the fact that among Coke's papers at Holkham Hall are geveral similar accounts on loose sheets saggests that he did not actuaijy collect them, st least as they now Btand. 
Jac. 2.' In the body of the paper mention is made of the various judges who were present at the transaction, and Justices Yelverton and Williams are mentioned in a parenthesis as beving just died. But Yelverton did not die till 30 Oct. 1612, and Williams died on 22 Jan. 1612-3. ${ }^{s}$ Horeover Fleming, mentioned as chief justice of the king's bench, and Tanfield, spoken of as chief baron, were not appointed till 25 June 1607. It is therefore impossible that if Coke wrote the paper he should have so dated it. On the other hand this same paper in the French manuscript copies is dated Hilary 10 Jac., which agrees much better with the facts. ${ }^{6}$ Still this is not correct, for January is within Hilary term; Williams died on 22 Jan., and yet is spoken of in the paper as being dead since 'last term.' A similarly incomprehensible miatake occurs in the account of Chancey's case." A writ of the high sommission there quoted is dated 19 March 1611-that is, 19-29 March 1611-12 N.S. Such a date cannot be correct, for Justices Walmesley and Williams are both mentioned in the report of this case, and Walmesley retired in Dec. $1611 .^{8}$ The proper date, 1610 , which we know from other sources, is given correctly in the manuscript copies. ${ }^{9}$ There is a report ${ }^{10}$ of a meeting of Coke with the archbishop of Canterbury at Lambeth, in which Coke defied the primate and refused to sit on the new high commission, of which he had been appointed a member. The date given at the top of the paper is 9 Jac. (i.e. 1611), bat in the body of the paper the archbishop is called by name, Archbishop Bancroft. As Bancroft died in November 1610, either the date or the name of the archbishop must be wrong. In the French copy the word 'Bancroft' is in parenthesis and in another handwriting than that in which the rest of the rolume is written." ${ }^{11}$ Probably Coke did not mention the name at all, but the copyist and editor thought it necessary.

The treatment which the fourth book of the Institutes, also published after Coke's death, received at the hands of its editors throws eome additional light apon the editing of the posthumous Reports.

The publisher of the third and fourth books of the Institutes, finding. as it should seem, some old notes, collected when the question [the dispate with the chancery] was on foot and undecided, had taken the boldness to print them, long after the anthor's death, and therein bad made him to question all again. . . And besides the supposed precedents which we have seen are not authentical, being most in torn papers, the rest of no credit. ${ }^{12}$

- Court and Timus of James $I, i .202,158 . \quad$ - Lansdopne MS. 601, t. 169.

TRop. xil. 82.

- Lansdowne MB. 601, t. 190 b.

"Iansdorne M8. 601, $\leq 197$ b.

12 A Vindication of the Judgment giten by King James in the Caen of the Juriediction of the Court of Chareery. 
Prynne ${ }^{1 s}$ also speaks of

my ardent and studious endeavors to benefit the present age and posterity to my power, by discovering sundry misquotations, mistakes of Rocords in our printed Law books, Reports, especially in the Institutes of that eminent Patron and Pillar of the Common Law, Sir Edward Coke ... published with some disadrantage to him and his Readers since his death, whose quotations (through too much credulity or supinenesse) are generally received, relied on by a meer implicit faith as Infallible Oracles, not only by most young Students and Professors, but most ancient Sages of the Law in their Arguments and Resolutions; yea, by many members of Parliament in their Debates and Conferences, without the least examination of their originals, when as upon strict search after and diligent comparing many of them with the Records themselves, they frequently prove to be either a nall tiel record or mistakes in their yesrs, numbers, and substance (and that probably for the most part by the default of the transcribers or printers of them, commonly guilty of Erratas in most impressions of Law books) . . . excited me to these seasonable if not necessary Animadversions on and Amendments of them ... I shall seriously advise all Professors and Students of the Common Law . . . to follow the author's advise, not to take anything upon trust, but to search the Fountains themselves, which I fear himself did not constantly pursue.

Many similar examples might be quoted, ${ }^{14}$ but these will suffice; the following inquiry will throw more doubt still upon the authenticity of the current edition of the Reports.

Of the famous meeting between Coke and the king we have four accounts-Coke's story, which is here quoted (in part) from the French text; Sir Julius Caesar's notes of the debate, taken in the meeting itself (as was his habit in all council meetings of importance); a letter from John Hercy to the earl of Shrewsbury; and a letter from Sir Rafe Boswell to Dr. Milborne.

\section{Coke's Account. ${ }^{13}$}

Nota sur le Jour de Soleil le 10 Jour de nonemlire in meme cest I erme le Roy, sur complaint faict al Roy per Bancroft, Archen: de Cant: concernent probibitions, le Roy fait informe que quant question fat taist de queux matters le eccticall Judge ed conusans ou sur lexposition de statt concernant Dismes on anter ascun chose eccticall on sur statt de $1^{\circ}$ Eliz. concernant le hault Commission ou sur ascun auter cas, est expresse authority in ley que le Roy meme poet ceo decede in Son Royall person, et que les Justices sont forsque delegates al Roy, et que le Roy poet

13 Brief Arimadvorsions on and Amendmonts of, and Additional Explanatory Records to, the Fourth Part of the 'Institutes of the Laras of England' (London, 1689), prefece to the reador.

1410 Barnewall and Cresswell, p. 275 ; 1 Barnewall and Alderson, p. 614 ; Woolryeh, Life of Cake, p. 921 ; Law Reviow, x7. 270, 281; Hobert'в Reports, p. 800, 80.

is Lanedowne M8. 601, f. 109. Mach of Coke's socount hes been omitted here, because it is littlo but oiting of precedent and may be found in the Reports. This omission gives the speooh a greater anity than it in tact possesses. 
prendre queux causes a luy pleist del determination des Judges et termine eux luy meme, et larchea: dit que cen fuit Cleere in Diainity que tiel Authority appent al Roy per parol do dieu in lescriptare. A que fuit responde per moy in le presence et ouec le Clecre consent de LLs les Justices Dengleterre et Barons del Exchequer que le Roy in son person dememe ne poet adiuger ascun case on Criminall come treson felony etc. ou inter party et party concernant son inheritance, Chatteux, ou bien, mes ceo doit estre determine et adiudge in Ascun Court de Justice, selonque le ley et Custome dengleterre et toutesfoite les Judgements sont done, et ideo consideratum est per ascun issint que le Court done iudgment, et le Roy ad Court, scilicet le upper meason de parliament, in que il ouec les Seignenrs est le supreme Judge sur tontes autres Judges. Car si error soit in le Common, coe serra reveree in banke le Roy et sil Court de Banke al Roy in Judgment, ceo serra reuerse in le upper house de parliament par le Roy ouec lassent des Segniors spiritual et temporall sans les Commons et in cest respect le Roy est appeale Ch. Justice. . . .

Donque le Roy dit que il pense que le ley fuit fondae sur reson et que ils auters ${ }^{16}$ ount reson cy biene come les Judges. a que fuit responde per moy que voyer fuit que Dieu ad indue son Maiesty ouec excellent science et grand endowements de natures, mes son Maiestie ne fuit erudite en les Leys de son reslme dangleterre et causes que concerne le vie ou inheritance ou biens ou fortunes del subiect ne sont decide per natural reson mes per le artificiall reson et Judgment del ley. que le fuete un arte que require long study et experience, devant que un poit attaine al Connusance de ce, ${ }^{17}$ et que le ley suite lo golden Metiand a mesurer et trier les Canses del subiect et que protecte son Maiesty in Safety et pesce. ouec quel le roy fuit grandment offend, et dit que donque il serra de south le ley, quil fuit treason daffirmer come il dit, a que jeo dje que Bracton dit quod Rex non debet esse sub homine sed sub deo et lege. ${ }^{18}$

\section{Caesar's Notes. ${ }^{19}$ Touching Prohibitions.}

The Irings Speech. That he came not to make or heare orations. That he expected an answere from the Judges after tuesday touching the 4 shires whether in the Jurisdiction of the Marches of Wales. This no lesse matter then robbing the Prince of Wales of his Jurisdiction, if the 4 shires bee denied to belong thereunto.

Now to the prohibitions against the ecclesiasticall Courtes. The question whether in a cause of tithes any Prescription or contract for tithes being alledged by the Defendant the carase bee then remoreable to the comon lawe.

Questions short. deliberations long. conolusions pithy. 2 E. 6. touching tithes. Articuli Cleri. circumspecte agatis. 9 E. 6 . the statute of 2 E. 6. expounded.

\footnotetext{
16 'Il et anters,' in Harleian MS. 4815-16. de ce.'

17 The Harleian MS. omite the passage, "que le fuete un arte. . . Connasance

11 ' Rex autem habet superiorem, Deum. Item legem per quam tactcs est rex. . . . Si rex fuerit sine traeno, id est sine lege, debent ei fraenum ponere' (Bracton, ii. ch. xvi. no. B).

1" Lansdowne MS. 160, ff. 428, 124.
} 
If thesn incident canses be tried at comon Lawe, no cause of tithes wilte held in the ecclesiasticall Courtes. The Judges are like the papistes. They alleadge scriptures and will interpret the same. The Judges alleadge etatutes and reserve the exposition thereof to themselves.

The comon lewe protecteth the king, quoth the L. Cooke. which the King said was a traiterous speech : for the King protecteth the lawe and not the lawe the King. The King maketh Judges and Bishops. If the Judges interprete the lawes themselves and suffer none else to interprete, then they may easily make of the laws ahipmens hose.

The King would haue both sides to seake out theire presidents touching the causcs of like nature heretofore; and then he will hear all at hie coming.

$$
\text { John Hercy to the Earl of Shrewsbury. }{ }^{30}
$$

On Sunday before the king's going to Newmarket (which was Sunday sennight) my Lord Coke and all the Judges of the Common law were before his Majesty to enswer some complaints made by the civil lawyers for the general granting of prohibitions. I heard that the Lord Coke amongst other offensive speeches should say to his Majesty that his Highness was defended by his laws. At which saying with other speeches then used by the Lord Coke, his Majesty was very much offended and told him he spake foolishly and said that he was not refended by bis laws but by God; and so gave the Lord Coke in other words a very sharp reprehension, both for that and for other things, and withal told him that Sir Thomas Crompton was as good a man as Coke, my Lrord Coke hrving by way of exception used some speech against Sir Thomas Crompton. Now not haring time and also for that (it being so long since) I partly think your Lordship before this by some other bath beard thereof, I forbear to inform you of all I have heard; but had not my Lord Treasurer most humbly on his knee, used many good words to pacify his Majesty, and to excuse that which had been spoken, it was thought his Highness would have been much more offended. In the conclusion, his Majesty, by the means of my Lord Treasurer, was well pacified, and geve a gracions countenance to all tho other Judges, and said he would maintain the Common Law. This canse, it is said, is again to be heard before his Majesty in the week before Christmas, at his Highnesg's return to Whitehall. . . .

\section{Sir Rafe Bostoell to Dr. Arilborne.91}

Besides I must tell you the Archbishop of Canterburie resolued to try the validitie of our letters patentes: whereof Bir Christofer [Parkins] did faythfally assure me, and which I understand likewise from many others neerest my lo. grace. Whereunto I presume his Lp. might be the rather encouraged in regard of the late high Grace shewed to him on Sunday last at Whitehall before the King, where the Prohibitions were Debsted by the Common laryers. There the lo. Coke humbly prayed the king to haue respect to the Common Lawes of his land etc. he prayed his Majesty to consider that the Ecclesiasticall Iurisdiction was forren. 
After which his Majestie fell into that high indignation as the like was. neuer knowne in him, looking and spesking fiercely with bended fist, offering to strike him etc., which the lo. Cooke percesuing fell flatt on all fower; humbly beseeching his Majestio to take compassion on him and to pardon him, if he thought zeale had gone beyond his dutie and allegiance. His Majesty not herewith contented, continued his indignation. Whereuppon the Lo. Treasurer, the lo. Cookes unckle by marrisge, kneeled downe before his Majestie and prayed him to be favourable. To whome his Majestie replied saying, what hast thou to doe to intreate for him. He aunswered in regard he hath married my neerest kinswoman. eto.

The first thing to establish is the date of this meeting. All the accounts agree that it took place on a Sunday, but as to the date and year they differ. Coke's account begins, 'Note upon Sunday, 10 Nov., in this same term,' without naming the year; and over it the editor has placed the date 'mich. 5 Jac.' Mr. Gurdiner accepts the heading and places the meeting in 1607, but notices that in the year 160710 Nor. fell upon Tuesday. He therefore dates it conjecturally 8 Nov. 1607. If the meeting happened in November 1607, it relates to Fuller's case, as Mr. Gardiner placed it, but it has nothing to do with Fuller's case. Neither Fuller nor the high commission nor its anthority is mentioned in any of the accounts we have of this meeting. Caesar's notes, on the other hand, are dated 13 Nor. 1608 ; and Caesar was, as any one who has handled many of his papers will at once recollect, most methodical in dating every paper that came into his hands. This date is confirmed by the letter of Hercy. He says the event happened on 'Sunday . . . which was Sunday se'nnight ;' and he dates his own letter most carefully, rendering it thereby the more trustworthy, - this present Friday, 25 Nor. 1608, at Westminster at 10 in the forenoon.' If 25 Nov. was Friday, as in 1608 it was, then the 'Sunday se'nnight' would fall on 13 Nov. Moreorer the French copy of Coke's account is dated ' 6 Jac.'-that is, 1608 . General considerations leave little doubt that this date is correct.

One other matter of date should be settled. The letter of Boswell to Milborne, though undoubtedly authentic, is in some ways peculiar. The text of the letter is a copy in an ordinary secretarial hand, underneath which, on the inside of the sheet, a second hand hes written, 'Sir Rafe Buswell and Dr. Milborne.' On the outside of the sheet a third hand has placed these names at the extreme top of the paper, and a fourth has added, at an angle below, a date, 'Feb. 1608.' It seems probable that this date was inserted some time after the copy of the letter was made, because it is not only in a different handwriting, but it is indefinite, the day of the month being omitted, and in addition is written at an angle below the names of the writers, whereas, 
according to seventeenth-century habits, the date would have been written at the top of the sheet, above the writers' nomes."

If the substance of Coke's account be scrutinised closely it will be apparent that instead of being a united whole it is composed of four parts, of which two relate to each other, and two are really not necessarily at all connected with each other or the rest of the doca. ment.

1. The preliminary statement that Bancroft told the king he might judge any cases he wished, taking the matter out of the hands of the courts.

2. Coke's answer, denying the contention : this begins with the words 'To which it was answered' and ends with the words 'but these were solely determined in the courts of justice.'

9. A great mass of precedents, not here reprinted, concerning the power of the king personally to arrest a man.

4. The often-quoted passage beginning with the words, "Then the king said that he thought the law was founded apon reason,' and ending with the famous sentence from Bracton.

Each of these four is in itself both in substance and style perfectly coherent and logical, but when compared the four do not agree. As far as substance is concerned the first and second sections agree very well; the third is an illustration of the second; and the fourth repeats in different and more offensive language what has already been said in the second. Yet in style the disagreement is more marked. The style of the first part is very involved, and indeed somewhat confused in construction. That of the second is clearer, but very heavy and tedious, with no turning of phrases. Part three is simply a list of precedents with a quotation or a word or two alout each. Then suddenly, without any warning or transition, we meet with this dramatic passage, full of keen phrases and rapid moverment. It seems too much to insiat that Coke could ever have delivered a speech in the shape in which these statements stand. It is even more improbable that James, shrewd as he was and good debater as he was, should have allowed the lord chief justice to demonstrate by precedents the truth of certain principles which James himself was clearly convinced were contrary to precedent and reason. Were this all the evidence we possessed, there would still be good resson for belioving that the paper we have is not in the shape in which Coke left it.

If now we check by the other papers what Coke has told, we shall find that they tell a somewhat brief bat exciting incident, and

\footnotetext{
* Mr. Gardiner acopted the date 'February 1608 ' (Hist. of Engl. ii. 41). It may be noticed that there are several inaccuracies in his referenos to the Hatfield manascripts. Thus ' 7 Nov.' should be ' 19 Oot.' (ibid. p. 39, noto 2). Here the writing is in Cecil's orn hand and perfectly clear.
} 
that in essentials they agree absolutely. MIoreover all these other accounts were written by people who had no interest in the matter or in the account which posterity received of it. Tro of them were, as far as we know, without any official position. Caesar had been master of requests, and as such had probably come in conflict with the judges, but he had had in all probability no difference with Coke. At the time he was under-treasurer and therefore not personally concerned in the question at issue. Nor had he any bias in favour of either side, for although a doctor of civil law he was also a prominent member of the Inner Temple. Moreorer all that he says is confirmed by the other accounts.

Caesar alone mentions the general debate before those remarks of Coke's which offended the king, and in this he is to be trusted, though he is not altogether as clear or as full as might be wished. He states that a debate took place orer the interpretation of the statutes concerning tithes. He mentions certain bitter speeches (which must be the king's) against the common l8w. He then gives Cole sir words, 'The common law protecteth the king,' fullowed by a few fiery sentences from the king. Next we find three words - ' the lord treasurer'-crossed out; and finally a conciliatory statement by the king. Now Coke's report gives the impression that the matter under debate was whether or not the king might draw cases from the law courts and decide them himself. This is improbable. James with his high ideas of the prerogative would never have suffered either the archbishop or Coke to debate the matter at all ; much less would he have summoned a council meeting to coneider it. ${ }^{23}$ For himself, he had no doubt upon the matter, and he was far too keen not to be aware that to debate it with the lord chief justice ras to call it in question. In fact, if he had been willing to debate such a matter as his prerogative, there is little reason to believe he would have become so angry over Coke's statement of his view. Moreover if this was the object in debate, and Coke believed the contrary so strongly, why had he not contradicted the king earlier, when James had made in other council meetings, when the judges were present, the most ertreme statements on the subject? On 6 Nor., therefore only the Banday before, Coke had been talking about the sacredness of the judges' oath. ${ }^{2 *}$ The king replied

that the King is theire Judge and it is his part to interpret theire othe, and not they; therefore required them to speake no more thereof,

$n$ - That onr prerogatire sbould not be wounded in that regard . . . we sent jou that direction; which we account to be wounded as well if it bo publicly disputed npon, as if any sentence pere given aquinst it' (the ling to Coke, May 1616; Spedding, Life and Letter of Bacon, v. 862). 'As for the absolate Prerogative of the Crown, that is no subject for the tongue of a lawyer, nor is lawful to be disputed ' (James I, Works, p. 550).

" Notas by Cecesar in Lansdopne MS. 160, 1.428. 
for that parcell of theire othe non differens Justitiam is not ment, when the King in his wisdome forbiddeth them to stay, for in disobeying his commandment therein they deserve to be hanged.

On 2 Nov. he had declared

the King the supreme judge; inferior judges his shadows and ministers ... a and the King may, if he please, sit and judge in Westminster Hall in any Court there, and call theire Judgments in question. . . The King beinge the author of the Lawe is the interpreter of the Lawe. ${ }^{25}$

Why did not Coke stand up in righteous wrath and hurl his precedents at James's head? Because we must recognise the fact that Coke had not the courage at that time to play the man to the extent his own account shows. In Caesar's notes of the debatess of 6 Nov. we also find this sentence, apparently a part of James's speech: 'The King but of six yeres standing in English Lawes and yet particeps rationis et ratio omnia legis.' And again the king asserted that 'to call in doubt thinges long time used by the Kinges of England in matters of this nature is little better than treason.' It is clear from these fragments that the king had no noed of the archbishop as an adrocate, nor did he get his notions about the prerogative from that prelate. He brought them with him from Scotland.

It is not probable that Coke's account in the Twelfth Reports, folio 65, describes one of these other meetings. The meetings of 2 and 6 Nov. were wholly occupied with the discussion of the jurisdiction of the council in the marches of Wales. The date of Coke's account, ' 10 Nov.,' fits these meetings even worse than that of the 13th. The sabject of them is even more foreign; for it has nothing to do with ecclesiastical matters at all, while Coke has a good deal to say about the arguments of the archbishop, who spoke against him. Nor, except in the fragments quoted above, do we meet anything about the king's prerogative, and those fragments were expressly headed by Caesar 'The King.' That, however, Coke meant in his account to describe the meeting of 13 Nov. may be inferred from the fact that 80 far as we know there was but one outbreak between the king and Coke. Three accounts agree that what offended the king was the statement that he was protected by the law. In Coke's account wo find these same worde: "which protecteth his majesty in safety and peace.' Carsar then-states that James replied that 'it was a traiterons speech,' which Coke phrased thus: 'which is treason to affirm.' These are the only two resemblances between Coke's account and the others, but these point to agreement in the matter of date.

There are likenesses between the speeches of the king quoted above and Coke's account. The phrase that the king is not

- Caesar's notes in Iansdowne MS. 160, 11. 186, 425, 128.

VOL. XVIII.-KO, I.xII. 
Oct.

experienced in English laws, a fragment which might stick in a man's memory, just as the sentence that he had law and reason as well as the judges, and the general fact of James's very.broad statement of his own prerogative, all appear at one place or another. Furthermore it is worth noting that the simile about the law as a metewand had been already used very effectively in Faller's printed pamphlet of 1607 , which, because of his opposition to the high commission, had attained some celebrity. Still, it was printed again in 1641 , was then in general circulation, and hence probably in the hands of Coke's editor; this passage may therefore be a later addition. The passage runs, 'which was always accompted one of the great blessings of this land, to have the law the meat-yeard and the jadges the measurers.'

Perhaps the best way of explaining Coke's paper will be something of this sort: Coke had attended these various meetings, certainly to the number of three or four, at which the king freely declared his ideas and carried matters against the common law. Coke became impatient and determined to express his opinion the next time the king made such remarks, and this accordingly on 13 Nov. he did. At some time after the event, probably not immediately, he indited the psper we possess. The main facts that he wished to preserve were the general statements of the royal right to try cases in peraon. Writing after a most exciting encounter, he conld not remember in much detail what was said, nor indeed did he probably care to do so. He did wish to leave to posterity (he clearly did not indite the paper for his own information) proof that he had been in the right; and so, after stating in a fow sentences that he bad replied the king might not sit personally as judge, he procoeded to add from his notebooks the precedents to support each argument. Then it occurred to him that the fact that the king could not in person legally arrest a man would bolster up his somewhat vague precedents in the matter of sitting in the courts of justice; so he added a number of precedents on that head, evidently meant as notes for reference, for each one began with Vide. He lastly wrote out a few phrases of the king's and what he thought he had replied, though the written speech was probably longer than his actual words. Moreover his memory confused the actual times at which these things had been said, and he really condensed into one short passage all the clever things James had said in several meetings. All this, it must be remembered, was written in law French and was translated by his editor in 1656, when the papers were published. Thus the finely turned English phrases are not Coke's but the work of some one else. How much we owe to the editor of the Reports will probably never be known.

A few words should be added harmonising the other papers, 
which all disagree with Coke but do not agree with each other in all details. The points of disagreement are clear, and none of the accounts should be trusted too fally. It is probably true that Coke never quoted Bracton to James at this moeting, bat that he fell flat on his face before the king also rests upon the authority of a single document. The really remarkable thing is not that these accounts should differ, for did they not differ somewhat there would be good reason to suspect them of being copies of some one document or of collusive preparation, but that they should agree so well in essentials. What struck Caesar as the cause of the king's anger were these words: 'The common law protecteth the king.' Hercy wrote to Shrewsbury 'that the lord Coke amongst other offensive speeches should say to his majesty that his highness was defended by his laws.' Boswell wrote to Milborne that ' the Lo: Coke humbly prayed the King to have respect to the Common Laws of his land etc. he prayed his Majesty to consider that the Ecclesiastical jurisdiction was forren.' But none of the three report the speech accredited to Coke in the Reports. That he said more than six words is clear, but that he made a long speech is incomprehensible. All three agree moreover upon the fact of the king's anger, and two say they do not tell all they heard. Naturally neither Caesar nor Shrewsbury would care to have in black and white the fact that Coke grovelled before the king, but Boswell might be expected to write it to Milborne. There is nothing im. probable in the story, but it is not proved. Two of the accounts also agree that the lord treasurer interfered and somewhat appeased James, and that had he not interposed Coke might have fallen under the king's heavy displeasure. These are the essential facts, and they are ascertained beyond reasonable doubt. Whether Coke quoted Bracton, or made strictures against Sir Thome. Crompton, or grovelled before James, is a minor point which does not at all alter the general result that he did not, ns his own report would lead us to believe, successfully beard the king.

RoLAND G. UsHer. 